\title{
Comparative evaluation of sulphur sources on growth, yield and quality of garlic (Allium sativum L.)
}

\section{G. Divyasree}

Department of Soil Science and Agricultural Chemistry, Directorate of Natural Resource Management, Tamil Nadu Agricultural University, Coimbatore - 641003 (Tamil Nadu), India

\section{R. K. Kaleeswari *}

Department of Soil Science and Agricultural Chemistry, Directorate of Natural Resource Management, Tamil Nadu Agricultural University, Coimbatore - 641003 (Tamil Nadu), India

\section{T. Chitdeshwari}

Department of Soil Science and Agricultural Chemistry, Directorate of Natural Resource Management, Tamil Nadu Agricultural University, Coimbatore - 641003 (Tamil Nadu), India

\section{R. Swarna Priya}

Department of Vegetable Science, Tamil Nadu Agricultural University, Coimbatore - 641003 (Tamil Nadu), India

\section{S. Karthikeyan}

Horticultural Research Station, Tamil Nadu Agricultural University, Ooty, The Nilgrisn - 643001 (Tamil Nadu), India

*Corresponding author Email: kaleeswarisenthur@gmail.com

\section{Article Info}

https://doi.org/10.31018/

jans.v13i4.3048

Received: September 25, 2021

Revised: November 5, 2021

Accepted: November 9, 2021

\section{How to Cite}

Divyasree, G. et al. (2021). Comparative evaluation of sulphur sources on growth, yield and quality of garlic (Allium sativum L.). Journal of Applied and Natural Science, 13(4), 1310 - 1316. https://doi.org/10.31018/jans.v13i4.3048

\begin{abstract}
Sulphur is a prime nutrient in Allium crops. Garlic fertilization with ammonium-based sulphur fertilizers in low pH soils is being practiced by farmers that culminate the soil acidity, which has an adverse effect on plant growth. Hence a field experiment was conducted at Horticultural Research Station, Woodhouse farm, Ooty, the Nilgris in 2021 to evaluate the appropriate sulphur sources and their levels for garlic at acidic hilly soil using four sulphur sources viz., potassium sulphate, magnesium sulphate, zinc sulphate and ammonium phosphate sulphate and three levels viz., 0, 40, $60 \mathrm{~kg} \mathrm{ha}^{-1}$. Garlic variety Ooty 2 was used as test crop. The results revealed that application of magnesium sulphate @ $60 \mathrm{~kg} \mathrm{ha}^{-1}$ produced the highest plant height, leaf numbers, clove numbers bulb ${ }^{-1}$, neck thickness, polar diameter, equatorial diameter, the weight of 10 cloves, fresh weight, dry weight and bulb yield $\left(16.78 \mathrm{t} \mathrm{ha}^{-1}\right)$ of garlic. Quality parameters viz., total soluble solids, ascorbic acid and total phenols of garlic bulbs were improved by the application of potassium sulphate @ $60 \mathrm{~kg} \mathrm{ha}^{-1}$. Sulphur source of Magnesium sulphate had a

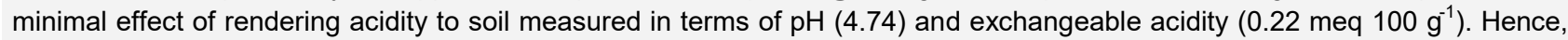
the promising source for acidic hilly soil and garlic crop was found to be magnesium sulphate @ $60 \mathrm{~kg}^{-1} \mathrm{~h}^{-1}$ followed by potassium sulphate @ $60 \mathrm{~kg} \mathrm{ha}^{-1}$. This particular investigation focuses not only on yield improvement but also on maintaining soil quality of the area.
\end{abstract}

Keywords: Acidity, Garlic, Source, Sulphur, Yield

\section{INTRODUCTION}

Garlic (Allium sativum L.) is a bulbous spice crop cultivated widely for more than 5000 years (Zhang et al., 2020). It is classified under Alliaceae family and had its origin in Central Asia. The vernacular names of Garlic are Vellaipoondu, Tellagadda, Velluli and Belluli. It is a frost hardy crop with shallow roots, propagated vegetatively. Garlic is the key ingredient in Indian kitchen, which also has high export potential. India holds second in garlic production after China. In India, major garlic growing states are Rajasthan, Uttar Pradesh, Gujarat and Punjab. The area under garlic cultivation in India is about 352000 ha with a production of 2925000 Mt during 2019-2020 (https://www.indiastat.com/ agriculture-data.aspx). In addition to culinary use, it contributes umpteen medicinal properties against medical disorders. It had received esteem in traditional and 
modern medicine as antimicrobial, antiprotozoal, antithrombotic, antidiabetic, antihypertensive, and anticarcinogenic (Singh et al., 2020). Garlic extract, along with ginger, is recognized as a pesticide and insecticide in organic farming. All these pharmacological values are ascribed to organosulphur compounds. Garlic contains more than thirty-three sulphur compounds such as allin, ajoene, allicin, diallyl trisulfide, allyl propyl disulfide, sallyl cysteine and others (Prati et al., 2014 and Fojlaley et al., 2020).

Sulphur is the essential secondary nutrient that plays a vital role in synthesising sulphur- containing aminoacids such as cysteine, cystine and methionine. It is a constituent of vitamin A and activates certain enzyme systems (Subramanian et al., 2020). Plants absorb sulphur in the form of sulphate $\left(\mathrm{SO}_{4}{ }^{2-}\right)$ ions from the soil and sulphur dioxide $\left(\mathrm{SO}_{2}\right)$ from air (Linzon et al.,1979). Mainly, plants depend upon soil for sulphur nutrition. Nutrient management in soil plays a vibrant role in increasing the productivity and quality of crops to feed the increasing human population. Most of the inorganic fertilizers provide a ready supply of nutrients for crop growth and its over-use can deteriorate soil health by acidification. Applying acid forming fertilizers to soils of low $\mathrm{pH}$ could further augment the acidity (Tong and $\mathrm{Xu}, 2012$ and Tabak et al., 2020). Keeping these facts in view, the present study attempted to evaluate the sulphur sources and optimize the sulphur levels for improving the growth and yield of garlic with minimal disruption of soil quality.

\section{MATERIALS AND METHODS}

\section{Study area}

A field experiment was conducted at the Horticultural Research Station research farm, Woodhouse farm, Ooty, The Nilgiris, from January to May of 2021. The site is located at $11.42446^{\circ} \mathrm{N}$ latitude, $76.72256^{\circ} \mathrm{E}$ longitude, and $2463 \mathrm{~m}$ above mean sea level. The experimental soil was analyzed in the laboratory to assess the initial properties and determined that the soil was clay loam in texture with a soil reaction of $\mathrm{pH} 4.98$ and EC 0.59 dS $\mathrm{m}^{-1}$. Soil available nutrients were low in $\mathrm{KMnO}_{4^{-}}$ Nitrogen (229 kg ha ${ }^{-1}$ ), high in Bray-Phosphorus (44.8 $\left.\mathrm{kg} \mathrm{ha}^{-1}\right)$, low in Neutral Normal $\mathrm{NH}_{4} \mathrm{OAc}$-potassium (220 $\mathrm{kg} \mathrm{ha}^{-1}$ ) and high in available sulphur (19.7 $\left.\mathrm{mg} \mathrm{kg}^{-1}\right)$.

\section{Treatments and experimental design}

Test crop garlic (var Ooty 2) cloves were planted at 15 $x 7.5 \mathrm{~cm}$ spacing. The treatments consisted of readily soluble type four sulphur sources (Potassium sulphate, Magnesium sulphate, Zinc sulphate and Ammonium phosphate sulphate) and three levels of sulphur $(0,40$, $60 \mathrm{~kg} \mathrm{~S} \mathrm{ha-1).} \mathrm{The} \mathrm{details} \mathrm{of} \mathrm{treatment} \mathrm{combinations}$ were viz., $\mathrm{T}_{1}-100 \% \mathrm{NPK}+0 \mathrm{~kg} \mathrm{~S} \mathrm{ha}{ }^{-1} \mathrm{~K}_{2} \mathrm{SO}_{4}, \mathrm{~T}_{2}-100$ $\% \mathrm{NPK}+40 \mathrm{~kg} \mathrm{~S} \mathrm{ha}{ }^{-1} \mathrm{~K}_{2} \mathrm{SO}_{4}, \mathrm{~T}_{3}-100 \% \mathrm{NPK}+60 \mathrm{~kg}$
$\mathrm{S} \mathrm{ha}^{-1} \mathrm{~K}_{2} \mathrm{SO}_{4}, \mathrm{~T}_{4}-100 \% \mathrm{NPK}+0 \mathrm{~kg} \mathrm{~S} \mathrm{ha}{ }^{-1} \mathrm{MgSO}_{4}, \mathrm{~T}_{5}$ $-100 \% \mathrm{NPK}+40 \mathrm{~kg} \mathrm{~S} \mathrm{ha}^{-1} \mathrm{MgSO}_{4}, \mathrm{~T}_{6}-100 \% \mathrm{NPK}+$ $60 \mathrm{~kg} \mathrm{~S} \mathrm{ha}{ }^{-1} \mathrm{MgSO}_{4}, \mathrm{~T}_{7}-100 \% \mathrm{NPK}+0 \mathrm{~kg} \mathrm{~S} \mathrm{ha}{ }^{-1}$ $\mathrm{ZnSO}_{4}, \mathrm{~T}_{8}-100 \% \mathrm{NPK}+40 \mathrm{~kg} \mathrm{~S} \mathrm{ha}{ }^{-1} \mathrm{ZnSO}_{4}, \mathrm{~T}_{9}-100$ $\% \mathrm{NPK}+60 \mathrm{~kg} \mathrm{~S} \mathrm{ha}^{-1} \mathrm{ZnSO}_{4}, \mathrm{~T}_{10}-100 \% \mathrm{NPK}+0 \mathrm{~kg}$ $\mathrm{S} \mathrm{ha}^{-1} \mathrm{APS}, \mathrm{T}_{11}-100 \% \mathrm{NPK}+40 \mathrm{~kg} \mathrm{~S} \mathrm{ha}^{-1} \mathrm{APS}, \mathrm{T}_{12}-$ $100 \% \mathrm{NPK}+60 \mathrm{~kg} \mathrm{~S} \mathrm{ha}{ }^{-1}$ APS. The design of the experiment was a factorial randomized block design. Main plots constituted sulphur sources and subplots depicted sulphur levels. The $100 \%$ NPK (75:40:40) was supplied as sulphur free fertilizers in the form of Calcium nitrate, Rock phosphate and Muriate of potash, respectively. Nitrogen, phosphorus, potassium and sulphur were applied basally and the top dressing of nitrogen was carried out at the bulb formation stage of crop growth. Cultural practices were implemented uniformly to all plots as per Tamil Nadu Agricultural University, Crop Production Guide Horticulture, 2020.

\section{Data collection and analysis}

Five garlic plants were labelled randomly from each plot for biometric observation. At the harvest stage, plant samples were collected for chemical analysis. Biometric observations were recorded on plant height (cm), number of leaves per plant, number of cloves per bulb, neck thickness $(\mathrm{cm})$, the weight of 10 cloves $(\mathrm{g})$, polar diameter $(\mathrm{cm})$, equatorial diameter $(\mathrm{cm})$, fresh weight of bulb (g), dry weight of bulb (g) and bulb yield $\left(\mathrm{t} \mathrm{ha} \mathrm{h}^{-1}\right)$. Total soluble solids of garlic bulbs were determined using ERMA portable handheld refractometer. The ascorbic acid was estimated as the dye titration method. The total phenols in the garlic bulbs were determined using Folin-ciocalteau reagent and gallic acid as a standard. The $\mathrm{pH}$ of soil was estimated by potentiometric principle (Jackson, 1973). The method employed by Sokolov (1939) and McLean (1965) was used for soil exchangeable acidity determination. The available sulphur was calculated by the turbidimetric method (Chesnin and Yien, 1950). The data obtained were put through statistical analysis of variance as proposed by Gomez and Gomez (1984) using SPSS statistical software version 26. The comparison of treatment effects was performed with Fisher's Least Significant Differences test at 0.05 level of significance. Treatments having differences were considered to be significant at $p<0.05$.

\section{RESULTS AND DISCUSSION}

\section{Effect of sulphur sources on growth parameters}

The sulphur sources and levels had a significant effect on plant height. The highest plant height, $67.13 \mathrm{~cm}$ was recorded in the treatment that received magnesium sulphate @ 60 kg ha-1 (Fig 1). Sulphur along with magnesium, being constituent of chlorophyll, gather photons in photosystem I and II encouraged vegetative 


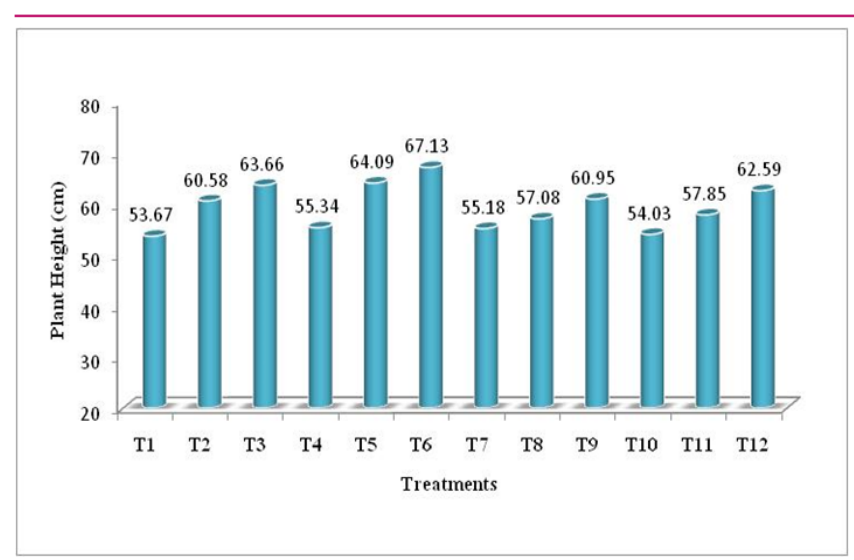

Fig 1. Effect of sulphur sources on plant height $(\mathrm{cm})$ of garlic

growth of plants (Chaudhry, 2021) and positive interaction of sulphur with nitrogen increase meristem activity of plants for growth (Verma et al., 2013). No significant interaction of sources and levels was observed. The present findings are in agreement with the results reported by Shete et al. (2018) in garlic @ $45 \mathrm{~kg} \mathrm{~S} \mathrm{ha}^{-1}$. Sulphur sources had no significant effect on the number of leaves. The maximum number of leaves was 6.88 , observed with magnesium sulphate @ $60 \mathrm{~kg} \mathrm{ha}^{-1}$ and was significantly influenced by sulphur levels (Fig 2). More number leaves provide a large surface area to receive sunlight helping in the food production of plants. Similar findings were also reported by Zaman et al. (2011) in garlic by supplying sulphur @ $45 \mathrm{~kg} \mathrm{ha}^{-1}$ and Priyanshu et al. (2019) recorded in garlic supplied with $40 \mathrm{~kg} \mathrm{~S} \mathrm{ha}^{-1}$ along with $\mathrm{FYM}$, vermicompost and $75 \%$ RDF.

\section{Effect of sulphur sources on yield and yield components}

Both sulphur sources and levels depicted significant differences in cloves per bulb and neck thickness. Application of magnesium sulphate @ $60 \mathrm{~kg} \mathrm{ha}^{-1}$ recorded the highest number of cloves per bulb and neck thickness with percent increase of $35 \%$ and $44 \%$, respectively, over control (Table 1). This is due to the function of sulphur and companion ion magnesium ranked importance in forming proteins, building blocks of the cell (Babaleshwar et al., 2017). In addition to the above points, favourable environmental conditions lead to fully differentiated cloves forming with the papery division between them.

The polar and equatorial diameter of the bulb varied significantly with sources, levels and its interaction. The polar and equatorial diameter significantly increased by $34 \%$ and $21 \%$, respectively, in the treatment that received magnesium sulphate @ $60 \mathrm{~kg} \mathrm{ha}^{-1}$ (Table 1). It

Table 1. Effect of sulphur sources and levels on yield attributes of garlic (var Ooty 2)

\begin{tabular}{|c|c|c|c|c|c|c|c|c|c|c|c|c|}
\hline \multirow{2}{*}{$\begin{array}{l}\text { Treatments } \\
T_{1}-100 \% N P K+0 \mathrm{~kg} \mathrm{~S} \text { ha }\end{array}$} & \multicolumn{3}{|c|}{ Cloves / bulb } & \multicolumn{3}{|c|}{$\begin{array}{l}\text { Neck thickness } \\
(\mathrm{cm})\end{array}$} & \multicolumn{3}{|c|}{$\begin{array}{l}\text { Polar bulb } \\
\text { diameter }(\mathrm{cm})\end{array}$} & \multicolumn{3}{|c|}{$\begin{array}{l}\text { Equatorial bulb } \\
\text { diameter }(\mathbf{c m})\end{array}$} \\
\hline & 12.35 & & & 1.39 & & & 3.02 & & & 3.31 & & \\
\hline $\mathrm{T}_{2}-100 \% \mathrm{NPK}+40 \mathrm{~kg} \mathrm{~S}$ & 15.66 & & & 1.63 & & & 4.15 & & & 4.44 & & \\
\hline $\mathrm{T}_{3}-100 \% \mathrm{NPK}+60 \mathrm{~kg} \mathrm{~S}$ & 16.71 & & & 1.85 & & & 4.20 & & & 4.49 & & \\
\hline $\mathrm{T}_{4}-100 \% \mathrm{NPK}+0 \mathrm{~kg} \mathrm{~S}$ & 13.11 & & & 1.28 & & & 3.32 & & & 3.61 & & \\
\hline $\mathrm{T}_{5}-100 \% \mathrm{NPK}+40 \mathrm{~kg} \mathrm{~S}$ & 16.84 & & & 1.66 & & & 4.23 & & & 4.52 & & \\
\hline $\mathrm{T}_{6}-100 \% \mathrm{NPK}+60 \mathrm{~kg} \mathrm{~S}$ & 17.67 & & & 1.92 & & & 4.46 & & & 4.75 & & \\
\hline $\mathrm{T}_{7}-100 \% \mathrm{NPK}+0 \mathrm{~kg} \mathrm{~S}$ & 13.08 & & & 1.34 & & & 2.93 & & & 3.22 & & \\
\hline $\mathrm{T}_{8}-100 \% \mathrm{NPK}+40 \mathrm{~kg} \mathrm{~S}$ & 14.82 & & & 1.55 & & & 3.75 & & & 4.04 & & \\
\hline $\mathrm{T}_{9}-100 \% \mathrm{NPK}+60 \mathrm{~kg} \mathrm{~S}$ & 15.40 & & & 1.76 & & & 4.08 & & & 4.37 & & \\
\hline $\mathrm{T}_{10}-100 \% \mathrm{NPK}+0 \mathrm{~kg} \mathrm{~S}$ & 12.85 & & & 1.31 & & & 3.52 & & & 3.81 & & \\
\hline $\mathrm{T}_{11}-100 \% \mathrm{NPK}+40 \mathrm{~kg} \mathrm{~S}$ & 13.63 & & & 1.52 & & & 3.58 & & & 3.87 & & \\
\hline $\mathrm{T}_{12}-100 \% \mathrm{NPK}+60 \mathrm{~kg} \mathrm{~S}$ & 14.95 & & & 1.68 & & & 3.96 & & & 4.25 & & \\
\hline Mean & $\begin{array}{l}14.75 \\
S\end{array}$ & $\mathrm{~L}$ & SxL & $\begin{array}{l}1.57 \\
S\end{array}$ & L & $S x L$ & $\begin{array}{l}3.77 \\
S\end{array}$ & L & SxL & $\begin{array}{l}4.06 \\
S\end{array}$ & L & SxL \\
\hline Sed & 0.41 & 0.35 & 0.71 & 0.04 & 0.04 & 0.08 & 0.1 & 0.09 & 0.18 & 0.11 & 0.1 & 0.19 \\
\hline $\mathrm{CD}(0.05)$ & 0.85 & 0.73 & NS & 0.09 & 0.08 & NS & 0.22 & 0.19 & 0.38 & 0.23 & 0.2 & 0.4 \\
\hline
\end{tabular}


is attributed to translocation of photosynthates efficiently from source to sinks paved for size increment of the bulb. Hore et al. (2014) also reported that sulphur @ 60 $\mathrm{kg} \mathrm{S} \mathrm{ha}^{-1}$ had a significant effect on the bulb diameter of garlic.

Bulb characteristics viz., fresh weight, dry weight of the bulb and 10 cloves weight were found to be significant at sulphur sources and levels. The treatment that received magnesium sulphate @ $60 \mathrm{~kg} \mathrm{ha}^{-1}$ recorded the maximum weight of bulb (Table 2). Increased photosynthesis, activation of phosphorylating enzymes and high affinity of RUBP carboxylase towards carbondioxide resulted in phloem loading and stored in bulbs of garlic (Al-Barzinji and Naif, 2014).

The bulb yield was significantly increased at a $5 \%$ level of significance in the treatment that received magnesium sulphate @ $60 \mathrm{~kg} \mathrm{ha}^{-1}$ with a $36 \%$ increase in yield followed a $16 \%$ increase by applying potassium sulphate @ $60 \mathrm{~kg} \mathrm{ha}^{-1}$ (Table 2). Magnesium and sulphur have synergistic effect on phosphorus uptake in plants that influence cell division. The increased root to shoot ratio altogether has high photosynthetic rate and accumulation of carbohydrates in bulbs, increasing its size and eventually resulting in maximum yield. Similar findings were in accordance with the results obtained from Choudhary et al.(2018) reported that sulphur application @ $60 \mathrm{~kg} \mathrm{ha}^{-1}$ in garlic enhanced the yield and Pati-

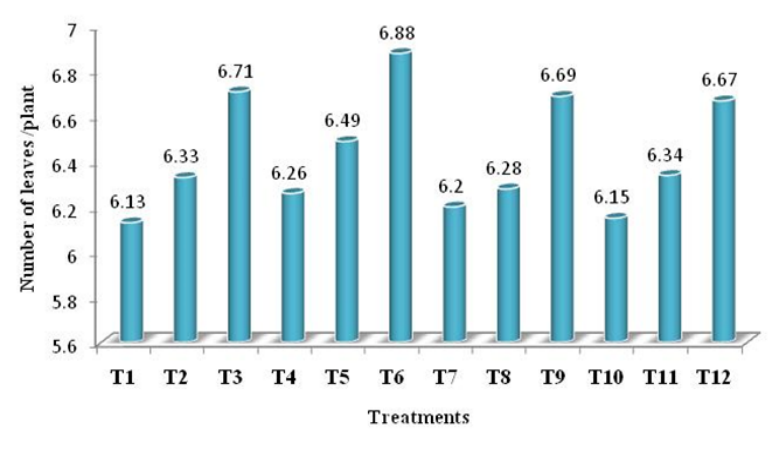

Fig 2. Effect of sulphur sources on number of leaves per plant of garlic

dar et al.(2017) who concluded sulphur nutrition @ 50 $\mathrm{kg} \mathrm{ha}^{-1}$ resulted in $27.5 \%$ increase in bulb yield of garlic over control.

The dry matter accumulation of bulb varied significantly at a $5 \%$ level of significance due to sulphur sources and levels. The application of magnesium sulphate registered a $25 \%$ increase of drymatter @ $60 \mathrm{~kg} \mathrm{ha}^{-1}$ (Fig $3)$ due to accelerated synthesis of chloroplast by higher uptake of sulphur and magnesium, resulting in more drymatter production. A similar finding was also reported by Diriba-Shiferaw et al. (2014) in garlic with sulphur application@ $30 \mathrm{~kg} \mathrm{ha}^{-1}$.

Table 2. Effect of sulphur sources and levels on bulb weight and yield of garlic (var Ooty 2)

\begin{tabular}{|c|c|c|c|c|c|c|c|c|c|c|c|c|}
\hline \multirow{2}{*}{$\begin{array}{l}\text { Treatments } \\
T_{1}-100 \% \mathrm{NPK}+0 \mathrm{~kg} \mathrm{~S}\end{array}$} & \multicolumn{3}{|c|}{$\begin{array}{l}\text { Weight of } 10 \\
\text { cloves }(\mathrm{g})\end{array}$} & \multicolumn{3}{|c|}{$\begin{array}{l}\text { Fresh weight of } \\
\text { bulb (g) }\end{array}$} & \multicolumn{3}{|c|}{$\begin{array}{l}\text { Dry weight of bulb } \\
\text { (g) }\end{array}$} & \multicolumn{3}{|c|}{$\begin{array}{l}\text { Bulb yield } \\
\left(\mathrm{t} \mathrm{ha}^{-1}\right)\end{array}$} \\
\hline & \multicolumn{3}{|c|}{10.73} & \multicolumn{3}{|c|}{11.69} & \multicolumn{3}{|l|}{4.03} & \multicolumn{3}{|l|}{13.28} \\
\hline $\mathrm{T}_{2}-100 \% \mathrm{NPK}+40 \mathrm{~kg} \mathrm{~S}$ & \multicolumn{3}{|l|}{12.15} & \multicolumn{3}{|c|}{15.92} & \multicolumn{3}{|l|}{6.57} & \multicolumn{3}{|c|}{14.72} \\
\hline $\mathrm{T}_{3}-100 \% \mathrm{NPK}+60 \mathrm{~kg} \mathrm{~S}$ & \multicolumn{3}{|l|}{13.28} & \multicolumn{3}{|c|}{18.34} & \multicolumn{3}{|l|}{6.72} & \multicolumn{3}{|c|}{15.43} \\
\hline $\mathrm{T}_{4}-100 \% \mathrm{NPK}+0 \mathrm{~kg} \mathrm{~S}$ & \multicolumn{3}{|l|}{10.54} & \multicolumn{3}{|c|}{12.27} & \multicolumn{3}{|l|}{4.34} & \multicolumn{3}{|c|}{12.34} \\
\hline $\mathrm{T}_{5}-100 \% \mathrm{NPK}+40 \mathrm{~kg} \mathrm{~S}$ & \multicolumn{3}{|l|}{13.43} & \multicolumn{3}{|c|}{17.46} & \multicolumn{3}{|l|}{6.38} & \multicolumn{3}{|c|}{15.37} \\
\hline $\mathrm{T}_{6}-100 \% \mathrm{NPK}+60 \mathrm{~kg} \mathrm{~S}$ & \multicolumn{3}{|l|}{14.74} & \multicolumn{3}{|l|}{21.9} & \multicolumn{3}{|l|}{7.07} & \multicolumn{3}{|c|}{16.78} \\
\hline $\mathrm{T}_{7}-100 \% \mathrm{NPK}+0 \mathrm{~kg} \mathrm{~S}$ & \multicolumn{3}{|l|}{10.11} & \multicolumn{3}{|c|}{12.18} & \multicolumn{3}{|l|}{4.18} & \multicolumn{3}{|c|}{12.25} \\
\hline $\mathrm{T}_{8}-100 \% \mathrm{NPK}+40 \mathrm{~kg} \mathrm{~S}$ & \multicolumn{3}{|l|}{11.45} & 14.85 & & & 5.55 & & & 13.47 & & \\
\hline $\mathrm{T}_{9}-100 \% \mathrm{NPK}+60 \mathrm{~kg} \mathrm{~S}$ & 12.87 & & & 16.57 & & & 6.41 & & & 14.88 & & \\
\hline $\mathrm{T}_{10}-100 \% \mathrm{NPK}+0 \mathrm{~kg} \mathrm{~S}$ & 10.69 & & & 11.2 & & & 4.23 & & & 12.69 & & \\
\hline $\mathrm{T}_{11}-100 \% \mathrm{NPK}+40 \mathrm{~kg} \mathrm{~S}$ & 11.05 & & & 14.01 & & & 5.56 & & & 13.02 & & \\
\hline $\mathrm{T}_{12}-100 \% \mathrm{NPK}+60 \mathrm{~kg} \mathrm{~S}$ & 12.62 & & & 14.98 & & & 6.2 & & & 13.98 & & \\
\hline Mean & 11.97 & & & 15.11 & & & 5.60 & & & 14.02 & & \\
\hline & S & $\mathrm{L}$ & SxL & S & $\mathrm{S}$ & $L$ & SxL & $S$ & $S$ & $\mathrm{~L}$ & SxL & $S$ \\
\hline Sed & 0.33 & 0.29 & 0.57 & 0.42 & 0.37 & 0.73 & 0.16 & 0.14 & 0.27 & 0.39 & 0.34 & 0.67 \\
\hline CD (0.05) & 0.69 & 0.60 & NS & 0.88 & 0.76 & 1.52 & 0.33 & 0.28 & 0.57 & 0.81 & 0.70 & NS \\
\hline
\end{tabular}




\section{Effect of sulphur sources on quality}

Application of sulphur recorded significant variations on quality parameters of garlic. Total soluble solids were registered to be the highest in the treatment that received potassium sulphate @ 60 kg ha ${ }^{-1}$ with $26 \%$ increase over unfertilized sulphur plot (Table 3 ). The valuable explanation is the supply of sulphur and potassium enhances the bulb's quality by activating starch synthetase enzyme in carbohydrate metabolism and translocation of sucrose transport from leaves to bulb. These results were in accordance with the findings observed by Chattoo et al. (2018) in garlic fertilized with sulphur @ 45 kg ha ${ }^{-1}$.

Results clearly showed no significant effect of sulphur sources on ascorbic acid of garlic (Table 3). Ascorbic acid content was the highest in the treatment that received potassium sulphate @ $60 \mathrm{~kg} \mathrm{ha}^{-1}$ and it was 12 $\%$ increase over no sulphur application.

Total phenols in the garlic bulb varied significantly at 5 $\%$ level of significance at the sulphur sources and levels (Table 3). The highest phenolic content was registered in the treatment that received potassium sulphate @ 60 kg ha ${ }^{-1}$ followed by magnesium sulphate @ 60 kg ha $^{-1}$. Synergistic interaction of potassium and sulphur boost potassium to express its role in quality improvement by activating over sixty enzyme systems was reported by Ozkan et al. (2018) in the onion crop nutritioned with potassium sulphate and polyhalite.

\section{Effect of sulphur sources on postharvest soil}

Though data on $\mathrm{pH}$ was found to be non-significant at 5 $\%$ level of significance, we could observe a gradual

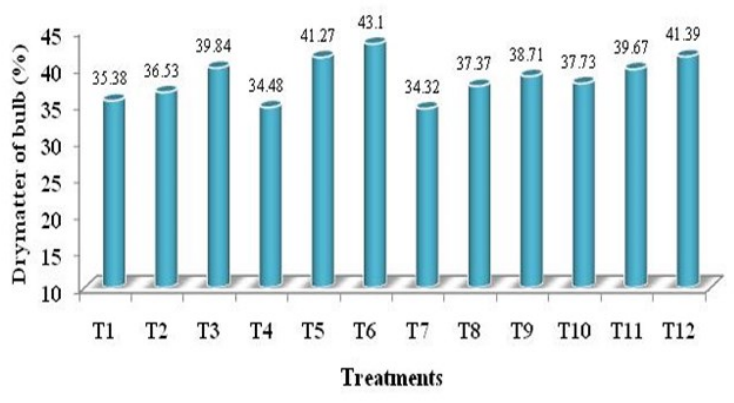

Fig 3. Effect of sulphur sources and levels on dry matter of garlic bulb (\%)

decrement of $\mathrm{pH}$ in levels of sulphur source. The decrease in $\mathrm{pH}$ recorded minimum of $3 \%$ with magnesium sulphate over no sulphur (Table 4). This indicates that there was an increase in hydrogen ion concentration that may be due to biochemical oxidation of sulphur producing sulphuric acid (Youssif et al., 2015) or reduction of nitrogen to ammonium ions.

The exchangeable acidity of soil varied significantly in terms of sulphur sources, levels and its interaction (Table 4). There was a rise in exchangeable acidity at sulphur levels. Sulphur source of magnesium sulphate contributed $29 \%$ increase in exchangeable acidity over control treatment which was recorded to be minimum than other sulphur sources rendering less acidity by furnishing meagre amount of acid cations to occupy on exchange sites of soil.

The build-up of available sulphur in post-harvest soil

Table 3. Effect of sulphur sources and levels on quality of garlic (var Ooty 2)

\begin{tabular}{|c|c|c|c|c|c|c|c|c|c|}
\hline \multirow{2}{*}{$\begin{array}{l}\text { Treatments } \\
\mathrm{T}_{1-1} 100 \% \mathrm{NPK}+0 \mathrm{~kg} \mathrm{~S} \mathrm{ha}^{-1} \mathrm{~K}_{2} \mathrm{SO}_{4}\end{array}$} & \multicolumn{3}{|c|}{$\begin{array}{l}\text { TSS } \\
\left({ }^{0} \text { Brix }\right)\end{array}$} & \multicolumn{3}{|c|}{$\begin{array}{l}\text { Ascorbic acid } \\
\left(\mathrm{mg} \mathrm{100g}^{-1}\right)\end{array}$} & \multicolumn{3}{|c|}{$\begin{array}{l}\text { Total phenols } \\
\left(\mathrm{mg} \mathrm{g}^{-1}\right)\end{array}$} \\
\hline & \multicolumn{3}{|c|}{34.18} & \multicolumn{3}{|c|}{18.25} & \multicolumn{3}{|c|}{0.36} \\
\hline $\mathrm{T}_{2}-100 \% \mathrm{NPK}+40 \mathrm{~kg} \mathrm{~S} \mathrm{ha}^{-1} \mathrm{~K}_{2} \mathrm{SO}_{4}$ & \multicolumn{3}{|l|}{40.72} & \multicolumn{3}{|c|}{19.87} & \multicolumn{3}{|l|}{0.44} \\
\hline $\mathrm{T}_{3}-100 \% \mathrm{NPK}+60 \mathrm{~kg} \mathrm{~S} \mathrm{ha}^{-1} \mathrm{~K}_{2} \mathrm{SO}_{4}$ & \multicolumn{3}{|l|}{43.16} & \multicolumn{3}{|c|}{20.81} & \multicolumn{3}{|l|}{0.49} \\
\hline $\mathrm{T}_{4}-100 \% \mathrm{NPK}+0 \mathrm{~kg} \mathrm{~S} \mathrm{ha}^{-1} \mathrm{MgSO}_{4}$ & \multicolumn{3}{|l|}{33.87} & \multicolumn{3}{|c|}{17.48} & \multicolumn{3}{|l|}{0.32} \\
\hline $\mathrm{T}_{5}-100 \% \mathrm{NPK}+40 \mathrm{~kg} \mathrm{~S} \mathrm{ha}{ }^{-1} \mathrm{MgSO}_{4}$ & \multicolumn{3}{|l|}{38.61} & \multicolumn{3}{|c|}{19.66} & \multicolumn{3}{|l|}{0.42} \\
\hline $\mathrm{T}_{6}-100 \% \mathrm{NPK}+60 \mathrm{~kg} \mathrm{~S} \mathrm{ha}^{-1} \mathrm{MgSO}_{4}$ & \multicolumn{3}{|l|}{41.89} & \multicolumn{3}{|c|}{20.74} & \multicolumn{3}{|l|}{0.48} \\
\hline $\mathrm{T}_{7}-100 \% \mathrm{NPK}+0 \mathrm{~kg} \mathrm{~S} \mathrm{ha}^{-1} \mathrm{ZnSO}_{4}$ & \multicolumn{3}{|l|}{33.22} & \multicolumn{3}{|c|}{18.39} & \multicolumn{3}{|l|}{0.33} \\
\hline $\mathrm{T}_{8}-100 \% \mathrm{NPK}+40 \mathrm{~kg} \mathrm{~S} \mathrm{ha}^{-1} \mathrm{ZnSO}_{4}$ & \multicolumn{3}{|l|}{36.14} & \multicolumn{3}{|c|}{19.27} & \multicolumn{3}{|l|}{0.4} \\
\hline $\mathrm{T}_{9}-100 \% \mathrm{NPK}+60 \mathrm{~kg} \mathrm{~S} \mathrm{ha}^{-1} \mathrm{ZnSO}_{4}$ & \multicolumn{3}{|l|}{39.27} & \multicolumn{3}{|c|}{20.03} & \multicolumn{3}{|l|}{0.45} \\
\hline $\mathrm{T}_{10}-100 \% \mathrm{NPK}+0 \mathrm{~kg} \mathrm{~S} \mathrm{ha}^{-1}$ APS & \multicolumn{3}{|l|}{33.41} & \multicolumn{3}{|c|}{17.52} & \multicolumn{3}{|l|}{0.34} \\
\hline $\mathrm{T}_{11}-100 \% \mathrm{NPK}+40 \mathrm{~kg} \mathrm{~S} \mathrm{ha}^{-1}$ APS & \multicolumn{3}{|l|}{35.53} & \multicolumn{3}{|c|}{19.43} & 0.39 & & \\
\hline $\mathrm{T}_{12}-100 \% \mathrm{NPK}+60 \mathrm{~kg} \mathrm{~S} \mathrm{ha}^{-1}$ APS & 38.05 & & & 19.92 & & & 0.44 & & \\
\hline Mean & 37.34 & & & 19.28 & & & 0.4 & & \\
\hline & $S$ & $\mathrm{~L}$ & $S x L$ & $S$ & $\mathrm{~L}$ & SxL & $S$ & $\mathrm{~L}$ & SxL \\
\hline Sed & 1.04 & 0.90 & 1.79 & 0.53 & 0.46 & 0.93 & 0.01 & 0.01 & 0.02 \\
\hline CD (0.05) & 2.15 & 1.86 & NS & NS & 0.96 & NS & 0.02 & 0.02 & NS \\
\hline
\end{tabular}


Table 4. Effect of sulphur sources and levels on properties of post harvest soil samples

\begin{tabular}{|c|c|c|c|c|c|c|c|c|c|}
\hline \multirow{2}{*}{$\begin{array}{l}\text { Treatments } \\
\mathrm{T}_{1-1} 100 \% \mathrm{NPK}+0 \mathrm{~kg} \mathrm{~S} \mathrm{ha}^{-1} \mathrm{~K}_{2} \mathrm{SO}_{4}\end{array}$} & \multicolumn{3}{|l|}{$\mathrm{pH}$} & \multicolumn{3}{|c|}{$\begin{array}{l}\text { Exchangeable acidity } \\
\left(\mathrm{meq} 100 \mathrm{~g}^{-1}\right)\end{array}$} & \multicolumn{3}{|c|}{$\begin{array}{l}\text { Available Sulphur } \\
\left(\mathrm{mg} \mathrm{kg}^{-1}\right)\end{array}$} \\
\hline & \multicolumn{3}{|l|}{4.92} & \multicolumn{3}{|c|}{0.16} & \multicolumn{3}{|c|}{13.33} \\
\hline $\mathrm{T}_{2}-100 \% \mathrm{NPK}+40 \mathrm{~kg} \mathrm{~S} \mathrm{ha}^{-1} \mathrm{~K}_{2} \mathrm{SO}_{4}$ & \multicolumn{3}{|l|}{4.83} & \multicolumn{3}{|l|}{0.20} & \multicolumn{3}{|c|}{22.35} \\
\hline $\mathrm{T}_{3}-100 \% \mathrm{NPK}+60 \mathrm{~kg} \mathrm{~S} \mathrm{ha}^{-1} \mathrm{~K}_{2} \mathrm{SO}_{4}$ & \multicolumn{3}{|l|}{4.68} & \multicolumn{3}{|l|}{0.26} & \multicolumn{3}{|c|}{24.01} \\
\hline $\mathrm{T}_{4}-100 \% \mathrm{NPK}+0 \mathrm{~kg} \mathrm{~S} \mathrm{ha}^{-1} \mathrm{MgSO}_{4}$ & \multicolumn{3}{|l|}{4.89} & \multicolumn{3}{|l|}{0.17} & \multicolumn{3}{|c|}{12.67} \\
\hline $\mathrm{T}_{5}-100 \% \mathrm{NPK}+40 \mathrm{~kg} \mathrm{~S} \mathrm{ha}^{-1} \mathrm{MgSO}_{4}$ & \multicolumn{3}{|l|}{4.86} & \multicolumn{3}{|l|}{0.19} & \multicolumn{3}{|c|}{21.33} \\
\hline $\mathrm{T}_{6}-100 \% \mathrm{NPK}+60 \mathrm{~kg} \mathrm{~S} \mathrm{ha}^{-1} \mathrm{MgSO}_{4}$ & \multicolumn{3}{|l|}{4.74} & \multicolumn{3}{|l|}{0.22} & \multicolumn{3}{|c|}{23.31} \\
\hline $\mathrm{T}_{7}-100 \% \mathrm{NPK}+0 \mathrm{~kg} \mathrm{~S} \mathrm{ha}^{-1} \mathrm{ZnSO}_{4}$ & \multicolumn{3}{|l|}{4.90} & \multicolumn{3}{|l|}{0.17} & \multicolumn{3}{|c|}{13.34} \\
\hline $\mathrm{T}_{8}-100 \% \mathrm{NPK}+40 \mathrm{~kg} \mathrm{~S} \mathrm{ha}^{-1} \mathrm{ZnSO}_{4}$ & \multicolumn{3}{|l|}{4.78} & \multicolumn{3}{|l|}{0.21} & \multicolumn{3}{|c|}{22.02} \\
\hline $\mathrm{T}_{9}-100 \% \mathrm{NPK}+60 \mathrm{~kg} \mathrm{~S} \mathrm{ha}^{-1} \mathrm{ZnSO}_{4}$ & \multicolumn{3}{|l|}{4.67} & \multicolumn{3}{|l|}{0.29} & \multicolumn{3}{|c|}{24.67} \\
\hline $\mathrm{T}_{10}-100 \% \mathrm{NPK}+0 \mathrm{~kg} \mathrm{~S} \mathrm{ha}^{-1} \mathrm{APS}$ & \multicolumn{3}{|l|}{4.92} & \multicolumn{3}{|l|}{0.17} & \multicolumn{3}{|c|}{12.54} \\
\hline $\mathrm{T}_{11}-100 \% \mathrm{NPK}+40 \mathrm{~kg} \mathrm{~S} \mathrm{ha}^{-1}$ APS & \multicolumn{3}{|l|}{4.71} & \multicolumn{3}{|l|}{0.29} & 21.83 & & \\
\hline $\mathrm{T}_{12}-100 \% \mathrm{NPK}+60 \mathrm{~kg} \mathrm{~S} \mathrm{ha}^{-1} \mathrm{APS}$ & 4.44 & & & 0.41 & & & 24.04 & & \\
\hline Mean & 4.78 & & & 0.23 & & & 19.62 & & \\
\hline & $S$ & L & SxL & $S$ & $\mathrm{~L}$ & SxL & $S$ & L & SxL \\
\hline Sed & 0.13 & 0.11 & 0.23 & 0.01 & 0.01 & 0.01 & 0.57 & 0.50 & 0.99 \\
\hline CD (0.05) & NS & NS & NS & 0.02 & 0.01 & 0.03 & NS & 1.03 & NS \\
\hline
\end{tabular}

samples was recorded to be non-significant in sulphur treated plots in terms of sulphur sources, whereas it was significant at sulphur levels (Table 4). Among the four sulphur sources, the zinc sulphate source recorded the maximum available sulphur status of $25.27 \%$ increase over the initial value. It indicates less uptake of sulphur in plants resulting in minimal performance compared to other sources. No increase in available sulphur status was registered in treatment that received other nutrients except sulphur. Similar findings were given by Thangasamy et al. (2013) in short-day onion supplied with (100:50:50) NPK kg ha ${ }^{-1}+50 \mathrm{~kg} \mathrm{ha}^{-1}$ sulphur and Solanki et al. (2020) in garlic fertilized with $5 \mathrm{t}$ $\mathrm{ha}^{-1}+40 \mathrm{~kg} \mathrm{~S} \mathrm{ha}^{-1}$.

The farming community still running behind the yield and quality improvement of crop while the area of attention has already been shifted in sustaining the soil health on par with crop production. Besides nutrients, sulphur is also a soil acidifier. All the sulphur sources compared here was easily soluble and readily available in the active pool of rhizospheric region that maintains dynamic equilibrium with exchangeable pool. Apart from evaluating the suitable sulphur fertilizer to the soils of low $\mathrm{pH}$ for enhancing garlic productivity, the present study gained momentum in assessing the fertilizer induced acidity both in active and exchangeable sites of soil.

\section{Conclusion}

It was inferred that among various sources of sulphur viz., potassium sulphate, magnesium sulphate, zinc sulphate, ammonium phosphate sulphate, the garlic plants fertilized with magnesium sulphate as sulphur source@ 60 kg ha ${ }^{-1}$ had a significant influence on the growth and yield of garlic by offering less acidity to the soil. Bulb quality was improved by potassium sulphate @ $60 \mathrm{~kg} \mathrm{ha}^{-1}$. Application of magnesium sulphate @ 60 $\mathrm{kg} \mathrm{ha}{ }^{-1}$ could be recommended for enhancing garlic growth and yield by sustaining soil quality.

\section{ACKNOWLEDGEMENTS}

The authors are thankful to the Department of Soil Science and Agricultural Chemistry, Tamil Nadu Agricultural University, Coimbatore and Horticultural Research Station, Ooty for providing lab facilities and field for research work.

\section{Conflict of interest}

The authors declare that they have no conflict of interest.

\section{REFERENCES}

1. Al-Barzinji, I. \& Naif, A. (2014). Effect of magnesium salts on growth and production of garlic (Allium sativum L.). ARO, The Scientific Journal of Koya University, 2(1), 1 -5. https://doi.org/10.14500/aro.10038

2. Babaleshwar, S. B., Koppad, S. R., Math, K. K. \& Dharmatti, R. (2017). Influence of sulphur on growth and yield of garlic (Allium sativum L.). J. Pharm. Phytochem, 6(5), 450-452.

3. Chattoo, M. A., Magray, M. M., Parray, F. A., Shah, M. D. \& Bhat, T. A. (2018). Effect of sulphur on growth, yield and quality of garlic (Allium sativum L.). Journal of Pharmacognosy and Phytochemistry, 7(5), 2894-2896.

4. Chesnin, L. \& Yien, C. H. (1950). Turbidimetric determination of available sulphates. In Soil Sci. Soc. Amer. Proc. 15,149-151https://doi.org/10.2136/sssaj1951.036159950 015000C0032x 
5. Chaudhry, A. H., Nayab, S., Hussain, S. B., Ali, M. \& Pan, Z. (2021). Current Understandings on Magnesium Deficiency and Future Outlooks for Sustainable Agriculture. International Journal of Molecular Sciences, 22(4), 1819.https://doi.org/10.3390/ijms22041819

6. Choudhary, K., Choudhary, M. R., Garhwal, O. P. \& Chahar, S. (2018). Effect of sowing date and sulphur levels on growth and yield of garlic (Allium sativum). Current Horticulture, 6(2), 48-51.

7. Crop production guide Horticulture crops. (2020), Government of Tamil Nadu and Tamil Nadu Agricultural University, Coimbatore, Tamil Nadu.

8. Diriba-Shiferaw, G., Nigussie-Dechassa, R., Woldetsadik, K., Sharma, J. J. \& Tabor, G. (2014). Bulb quality of garlic (Allium sativum L.) as influenced by the application of inorganic fertilizers. African Journal of Agricultural Research, 9(8),784-796.https://doi.org/10.5897/AJAR2013.7 723

9. Fojlaley, M., Kalkan, F. \& Ranji, A. (2020). Drying Process of Garlic and Allicin Potential-A Review. World, 9(4), 5054.

10. Gomez, K. A. \& Gomez, A. A. (1984). Statistical procedures for agricultural research. John Wiley \& Sons.

11. Hore, J. K., Ghanti, S. \&Chanchan, M. (2014). Influence of nitrogen and sulphur nutrition on growth and yield of garlic (Allium sativum L.). Journal of Crop and Weed, 10(2), 1418.

12. Jackson, M. L. (1973). Soil chemical analysis. Prentice Hall of India Pvt. Ltd., New Delhi.

13. Linzon, S. N., Temple, P. J. \& Pearson, R. G. (1979). Sulfur concentrations in plant foliage and related effects. Journal of the Air Pollution Control Association, 29 (5), 520-525. https://doi.org/10.1080/00022470.1979.10 470822

14. McLean, E. O. (1965). Aluminum. Methods of Soil Analysis: Part 2 Chemical and Microbiological Properties, 9 , 978-998. https://doi.org/10.2134/agronmonogr 9.2.c16

15. Ozkan, C. F., Anac, D., Eryuce, N., Demirtas, E. L., Asri, F. O., Guven, D., Simsek, M. \& Ari, N. (2018). Effect of different potassium and sulfur fertilizers on onion (Allium cepa L.) yield and quality. Electronic International Fertilizer Correspondent (e-ifc), (53), 16-24.

16. Patidar, M., Shaktawat, R. P. S. \& Naruka, I. S. (2017). Effect of sulphur and vermicompost on growth, yield and quality of garlic (Allium sativum L.). Journal of Krishi Vigyan, 5(2), 54-56. DOI10.5958/2349-4433.2017.00 01 2.5

17. Prati, P., Henrique, C. M., Souza, A. S. D., Silva, V. S. N. D. \& Pacheco, M. T. B. (2014). Evaluation of allicin stability in processed garlic of different cultivars. Food Science and Technology, 34, 623-628. https://doi.org/10.15 90/16 78-457x.6397

18. Priyanshu, A. B., Singh, M. K., Malik, S., Kumar, M., Kumar, V., Tripathi, S. K. \& Shahi, U. P. (2019). Effect of integrated nutrient management on growth characters of garlic (Allium sativum L.) CV. Yamuna Safed3. Progressive Agriculture, 19(2), 242-246. DOI: 10.595 8/0976-4615.2019.00042.5

19. Shete, M. B., Chiktey, H. M., Jadhav, S. B. \&Bhalekar, M. N. (2018). Effect of sulphur on growth, yield and quality of garlic (Allium sativum L.). International Journal of Chemical Studies,6(1), 552-555.

20. Singh, R. N., Kumar, P., Kumar, N. \& Singh, D. K. (2020). Garlic (Allium sativum) :pharmaceutical uses for human health. International Journal of Pharmaceutical Sciences and Research, 11(9), 4214-4228.

21. Sokolov, A. V. (1939). Kimizastia sots zemledelia, 7, C. f. Journal of the Indian Society of Soil Science, 246.

22. Solanki, S. S., Chaurasiya, A., Mudgal, A., Mishra, A. \& Singh, A. K. (2020). Effect of soil application of sulphur, farm yard manure and vermicompost on soil fertility, growth and yield of garlic (Allium sativum L.). IJCS, 8(1), 1370-1373.

23. Subramanian, M. S., Nandagopal MS, G., Amin Nordin, S., Thilakavathy, K. \& Joseph, N. (2020). Prevailing knowledge on the bioavailability and biological activities of sulphur compounds from alliums: a potential drug candidate. Molecules, 25(18), 4111. https://doi.or $\mathrm{g} / 10.3390 /$ molecules25184111

24. Tong, D. \& Xu, R. (2012). Effects of urea and (NH4) $2 \mathrm{SO} 4$ on nitrification and acidification of Ultisols from Southern China. Journal of Environmental Sciences, 24(4), 682689.

25. Thangasamy, A., Sankar, V. \& Lawande, K. E. (2013). Effect of sulphur nutrition on pungency and storage life of short day onion (Allium cepa). Indian Journal of Agricultural Sciences, 83(10), 1086-1089.

26. Tabak, M., Lisowska, A., Filipek-Mazur, B. \& Antonkiewicz, J. (2020). The effect of amending soil with waste elemental sulfur on the availability of selected macroelements and heavy metals. Processes, 8(10), 1245.doi:1 $0.3390 / p r 8101245$

27. Verma, S., Choudhary, M. R., Yadav, B. L. \& Jakhar, M. L. (2013). Influence of vermicompost and sulphur on growth and yield of garlic (Allium sativum L.) under semi arid climate. Journal of spices and aromatic crops, 22(1), 20-23.

28. Youssif, B. D., Hosna, M. A. F. \& Mervat, A. A. T. (2015). Effect of Sulphur and Sulphur oxidizing bacteria on growth and production of garlic (Allium sativum L.) under saline conditions. Middle East J. Agric. Res, 4(3), 446-459.

29. Zaman, M. S., Hashem, M. A., Jahiruddin, M. \& Rahim, M. A. (2011). Effect of sulphur fertilization on the growth and yield of garlic (Allium sativum L.). Bangladesh Journal of Agricultural Research, 36(4), 647-656.

30. Zhang, Y., Liu, X., Ruan, J., Zhuang, X., Zhang, X.\& Li, Z. (2020). Phytochemicals of garlic: Promising candidates for cancer therapy. Biomedicine \& Pharmacotherapy, 123, 109730. 